\title{
ANALISIS KUALITAS SOAL PRA UJIAN NASIONAL MATA PELAJARAN EKONOMI AKUNTANSI
}

\section{QUALITY ANALYSIS OF PRE NATIONAL EXAMINATION QUESTIONS IN ECONOMIC-ACCOUNTING SUBJECT}

\author{
Oleh: \\ Rahmatika Rahayu \\ Prodi Pendidikan Akuntansi Universitas Negeri Yogyakarta \\ rahmetika@gmail.com \\ M. Djazari \\ Staf Pengajar Jurusan P. Akuntansi Universitas Negeri Yogyakarta
}

\begin{abstract}
Abstrak
Penelitian ini bertujuan untuk mengetahui Validitas, Reliabilitas, Tingkat Kesukaran, Daya Pembeda, dan Efektivitas Pengecoh soal Pra Ujian Nasional Mata Pelajaran Ekonomi Akuntansi Kelas XII IIS SMA Negeri 1 Magelang. Metode pengumpulan data dilakukan dengan menggunakan metode dokumentasi untuk mendapatkan data yang meliputi soal, kunci jawaban, kisi-kisi soal dan lembar jawab siswa. Teknik analisis data yang digunakan adalah teknik deskriptif kuantitatif. Hasil penelitian ini menunjukkan bahwa ditinjau dari: (1) Validitas, soal yang valid berjumlah 29 butir (72,5\%), dan tidak valid 11 butir (27,5\%). (2) Reliabilitas, soal memiliki Reliabilitas rendah dengan koefisien Reliabilitas sebesar 0,62 (3) Tingkat Kesukaran, soal yang tergolong sukar berjumlah 6 butir (15\%), sedang 24 butir (60\%), dan mudah 10 butir (25\%). (4) Daya Pembeda, butir soal dengan Daya Pembeda jelek 13 butir (32,5\%), Daya Pembeda sedang 17 butir (42,5\%), Daya Pembeda baik 8 butir (20\%) dan Daya Pembeda negatif 2 butir (5\%). (5) Efektivitas Pengecoh, Butir soal dengan Efektivitas Pengecoh sangat baik 5 butir (12,5\%), Efektivitas Pengecoh baik 5 butir (12,5\%), Efektivitas Pengecoh kurang baik 16 butir (40\%), Efektivitas Pengecoh tidak baik 8 butir (20\%), Efektivitas Pengecoh sangat tidak baik 6 butir $(15 \%)$.

Kata kunci: Validitas, Reliabilitas, Tingkat Kesukaran, Daya Pembeda, Efektivitas Pengecoh, Soal Pra Ujian Nasional, Ekonomi Akuntansi
\end{abstract}

\begin{abstract}
The research aimed to acknowledge Validity, Reliability, Level of Difficulty, Item Discrimination and Distraction Effectiveness of Economic-Accounting Pre National Examination question SMA Negeri 1 Magelang. Data collection is done by using is the method of documentation to collect the data which include the test questions, answer key, and answer sheets. Data analysis technique used is quantitative descriptive analysis technique. The result brings to the conclusion that in terms of: (1) Validity, there are 29 valid items (72,5\%) and 11 invalid items (27,5\%). (2) Reliability, items have a low Reliability with Reliability coefficient are at 0,62. (3) Level of Difficulty, there are 6 hard items (15\%), 24 average items (60\%) and 10 easy items (25\%). (4) Item Discrimination, 13 items $(32,5 \%)$ were poor, 17 items (42,5\%) were fair, 8 items (20\%) were good and 2 items (5\%) were very poor. (5) Distraction Effectiveness, there are 5 items (12,5\%) which have very good distraction level, 5 items (12,5\%) which have good distraction level, 16 items (40\%) which has less distraction level, 8 items (20\%) which has poor distraction level and 6 items (15\%) which has very poor distraction level. Keywords: Validity, Reliability, Level of Difficulty, Item Discrimination,Distraction Effectiveness, Pre National Examination Questions, Economic-Accounting
\end{abstract}




\section{PENDAHULUAN}

Dalam dunia pendidikan, guru memegang peran yang sangat penting terhadap keberhasilan siswa. Secara garis besar, tugas utama seorang guru yakni merencanakan pembelajaran, melaksanakan pembelajaran dan menilai proses serta hasil pembelajaran. Penilaian proses maupun hasil pembelajaran yang dilakukan untuk mengetahui kemampuan siswa dan untuk mengetahui tingkat keberhasilan pembelajaran sering dikenal dengan istilah evaluasi. Menurut Anas Sudijono (2015: 5), evaluasi adalah kegiatan atau proses untuk menilai sesuatu dan untuk dapat menentukan nilai dari sesuatu yang sedang dinilai tersebut, dilakukanlah pengukuran. Wujud dari pengukuran tersebut adalah pengujian yang dalam dunia pendidikan dikenal dengan istilah tes.

Evaluasi dilakukan dengan tujuan untuk memperoleh data pembuktian, yang akan menjadi petunjuk sampai di mana tingkat kemampuan dan tingkat keberhasilan peserta didik dalam pencapaian tujuantujuan kurikuler setelah mereka menempuh proses pembelajaran dalam jangka waktu yang telah ditentukan serta untuk mengukur dan menilai sampai di manakah efektivitas mengajar dan metode-metode mengajar yang telah diterapkan atau dilaksanakan oleh pendidik (Anas Sudijono, 2015: 16).

Salah satu teknik yang digunakan untuk melakukan evaluasi terhadap hasil belajar siswa yaitu dengan tes. Tes adalah cara atau prosedur yang perlu ditempuh dalam rangka pengukuran dan penilaian di bidang pendidikan, yang berbentuk pemberian tugas atau serangkaian tugas berupa pertanyaan-pertanyaan yang harus dijawab atau perintah-perintah yang harus dikerjakan oleh testee, sehingga dapat dihasilkan nilai yang melambangkan tingkah laku atau prestasi testee (Anas Sudijono, 2015: 67)

Suatu tes yang diujikan kepada siswa harus memiliki kualitas yang baik. Tes yang berkualitas dapat memberikan informasi yang sesungguhnya mengenai hasil belajar siswa, sehingga informasi tersebut dapat digunakan untuk mengukur tingkat perkembangan atau kemajuan yang telah dicapai oleh peserta didik setelah mereka menempuh proses belajar mengajar dalam jangka waktu tertentu. Di samping itu, informasi yang diperoleh dari tes yang berkualitas dapat digunakan untuk mengetahui sudah seberapa jauh program pengajaran yang telah ditentukan dapat tercapai (Anas Sudijono, 2015: 67).

Menurut Nana Sudjana (2014: 12), suatu alat penilaian (tes) dikatakan mempunyai kualitas yang baik apabila alat tersebut memenuhi dua hal, yakni ketepatan atau validitas dan ketetapan atau keajegan atau reliabilitas. Anas Sudijono (2015: 370) menjelaskan bahwa penganalisisan terhadap butir-butir soal tes hasil belajar agar memiliki kualitas yang tinggi dapat dilakukan dari tiga segi yaitu dari segi tingkat kesukaran itemnya, dari segi daya pembeda itemnya dan dari segi fungsi distraktornya (fungsi pengecoh).

Soal tes yang berkualitas tersusun atas butir-butir soal yang berkualitas pula. Agar dapat mengetahui kualitas suatu soal tes, maka perlu dilakukan analisis terhadap kualitas soal. Analisis kualitas soal merupakan suatu tahap yang harus ditempuh untuk mengetahui derajat kualitas suatu soal tes, baik secara keseluruhan maupun butir soal yang menjadi bagian dari soal tes tersebut. Analisis kualitas soal yang dimaksudkan adalah analisis yang ditinjau dari masing-masing aspek Validitas, Reliabilitas, Tingkat Kesukaran dan Efektivitas Pengecoh. Analisis Validitas dan Reliabilitas dapat digunakan untuk mengetahui kualitas soal secara keseluruhan, sedangkan analisis Tingkat Kesukaran, Daya Pembeda dan Efektivitas Pengecoh digunakan untuk mengetahui kualitas butir soal. Analisis Tingkat Kesukaran maupun Daya Pembeda dapat digunakan untuk mengukur kualitas butir soal objektif dan uraian. 
Salah satu tujuan dilakukannya analisis terhadap kualitas soal adalah untuk meningkatkan kualitas soal, yaitu apakah suatu soal telah dapat diterima, perlu diperbaiki karena memiliki beberapa kelemahan atau tidak digunakan sama sekali karena tidak berfungsi (Sumarna Surapranata, 2009: 10-11).

Akan tetapi, masih banyak guru yang belum melakukan analisis terhadap soal tes yang dibuat karena menganggap bahwa menganalisis kualitas soal tes memerlukan waktu yang lama dan juga membutuhkan banyak tenaga. Akibatnya, banyak butir soal yang digunakan dalam tes tidak dapat menghasilkan data yang benar atau akurat tentang hasil belajar siswa. Apabila keputusan yang diambil didasarkan pada data yang tidak benar atau tidak akurat, yang disebabkan oleh instrumen yang digunakan untuk mengumpulkan data tidak disusun secara baik, maka keputusan tersebut merupakan keputusan yang tidak dapat dipertanggungjawabkan (Eko Putro Widoyoko, 2014: 130).

Berdasarkan observasi yang dilakukan di SMA Negeri 1 Magelang pada tanggal 7 Desember 2015, diketahui bahwa guru belum pernah menganalisis kualitas soal Pra Ujian Nasional. Penganalisisan kualitas soal yang dilakukan oleh guru hanya secara sederhana yakni dengan menghitung jumlah siswa yang dapat mengerjakan soal dengan benar dan siswa yang tidak bisa mengerjakan serta membandingkan soal mana yang banyak dijawab benar oleh siswa dan soal mana yang banyak mendapatkan jawaban salah dari siswa. Hal tersebut belum sesuai dengan apa yang seharusnya dilakukan oleh guru untuk mengukur hasil belajar siswa serta hasil pembelajaran di dalam kelas.

Agar dapat mengetahui kualitas soal Pra Ujian Nasional Mata Pelajaran Ekonomi Akuntansi Kelas XII IIS SMA Negeri 1 Magelang yang ditinjau dari aspek Validitas, Reliabilitas, Tingkat Kesukaran, Daya Pembeda dan Efektivitas Pengecoh, perlu diadakan penelitian yang berjudul "Analisis Kualitas Soal Pra Ujian Nasional Mata Pelajaran Ekonomi Akuntansi Kelas XII IIS SMA Negeri 1 Magelang Tahun Ajaran 2015/2016".

Tujuan dari penelitian ini yaitu untuk mengetahui Validitas, Reliabilitas, Tingkat Kesukaran, Daya Pembeda, dan Efektivitas Pengecoh soal Pra Ujian Nasional Mata Pelajaran Ekonomi Akuntansi Kelas XII IIS SMA Negeri 1 Magelang Tahun Ajaran 2015/2016.

Hasil penelitian ini diharapkan dapat memberi manfaat bagi berbagai pihak. Bagi guru penelitian ini dapat untuk mengetahui kualitas soal yang dibuat, sehingga guru memiliki acuan untuk melakukan tindak lanjut terhadap soal yang dibuatnya. Bagi peneliti yaitu untuk menambah wawasan dan pengalaman mengenai penerapan ilmu evaluasi pendidikan khususnya pada bidang analisis kualitas soal.

\section{METODE PENELITIAN Desain Penelitian}

Desain penelitian ini yaitu penelitian deskriptif kuantitatif. Menurut Best (dalam Sukardi, 2013: 157), yang dimaksud dengan penelitian deskriptif yaitu metode penelitian yang berusaha menggambarkan dan menginterpretasi objek sesuai dengan apa adanya. Nana Syaodih (2012: 53) menjelaskan bahwa penelitian kuantitatif merupakan penelitian yang menekankan fenomenafenomena objektif yang dikaji secara kuantitatif yaitu menggunakan angka-angka, pengolahan statistik, struktur, dan percobaan terkontrol. Dalam pelaksanaannya, penelitian ini bermaksud untuk mencari data yang dapat digunakan untuk mendeskripsikan Validitas, Reliabilitas, Tingkat Kesukaran, Daya Pembeda dan Efektivitas Pengecoh soal Pra Ujian Nasional Mata Pelajaran Ekonomi Akuntansi Kelas XII IIS SMA Negeri 1 Magelang Tahun Ajaran 2015/2016. Data yang diperoleh kemudian diwujudkan dalam bentuk angka-angka dan 
dianalisis menggunakan program komputer Anates Versi 4 dan Microsoft Excel 2010.

\section{Tempat dan Waktu Penelitian}

Penelitian ini dilakukan di SMA Negeri 1 Magelang pada bulan Januari sampai dengan Februari 2016.

\section{Subjek dan Objek}

Subjek dalam penelitian ini adalah siswa kelas XII IIS SMA Negeri 1 Magelang dan objek penelitian ini adalah soal Pra Ujian Nasional Mata Pelajaran Ekonomi Akuntansi Kelas XII IIS SMA Negeri 1 Magelang Tahun Ajaran 2015/2016.

\section{Data dan Teknik Pengumpulan}

Data yang digunakan dalam penelitian ini adalah soal Pra Ujian Nasional Mata Pelajaran Ekonomi Akuntansi, kunci jawaban, kisi-kisi soal dan lembar jawab siswa. Teknik pengumpulan data yaitu menggunakan teknik dokumentasi.

\section{Teknik Analisis Data}

Teknik analisis data yang digunakan dalam penelitian ini adalah teknik analisis data deskriptif kuantitatif. Data yang diperoleh kemudian diolah dengan menggunakan bantuan program komputer Anates Versi 4 untuk mengetahui Validitas, Reliabilitas, Tingkat Kesukaran, Daya Pembeda dan Efektivitas Pengecoh.

\section{a. Validitas}

Validitas mencerminkan sejauh mana soal dapat dengan tepat mengukur apa yang seharusnya diukur. Penentuan Validitas atau daya ketepatan mengukur dapat ditentukan dengan dua cara yaitu dengan melakukan penganalisisan yang dilakukan secara logis atau rasional dan penganalisisan yang dilakukan berdasarkan pada kenyataan empiris. Validitas empiris diketahui dengan menghitung Validitas butir soal. Teknik analisis yang digunakan untuk mengetahui Validitas butir soal adalah teknik korelasi point biserial dengan rumus sebagai berikut:

$$
-r_{p b i}=\frac{M_{p}-M_{t}}{S D_{t}} \sqrt{\frac{p}{q}}
$$

Keterangan:

$\mathrm{r}_{\mathrm{pbi}}=$ Koefisien korelasi point biserial

$\mathrm{M}_{\mathrm{p}}=$ Skor rata-rata hitung yang dimiliki oleh testee, yang untuk butir item yang bersangkutan telah dijawab dengan benar

$\mathrm{M}_{\mathrm{t}}=$ Skor rata-rata dari skor total $\mathrm{SD}_{\mathrm{t}}=$ Deviasi standar dari skor total

$\mathrm{p}=$ Proporsi testee yang menjawab benar

$\mathrm{q}=$ Proporsi testee yang menjawab salah

(Anas Sudijono, 2015: 185)

Indeks korelasi point biserial $\left(\mathrm{r}_{\mathrm{pbi}}\right)$ yang diperoleh dari hasil perhitungan kemudian dikonsultasikan dengan $r_{\text {tabel }}$ pada taraf signifikansi 5\% sesuai dengan jumlah subjek yang diteliti. Soal dikatakan valid apabila $\mathbf{r}_{\text {pbi }}$ lebih besar dari $\mathbf{r}_{\text {tabel. }}$.

b. Reliabilitas

Reliabilitas soal berkaitan dengan suatu perangkat soal apabila diujikan kepada subjek yang sama secara berulang kali menunjukkan keajegan atau kestabilan hasil. Rumus yang digunakan untuk menghitung Reliabilitas tes hasil belajar bentuk objektif yaitu dengan menggunakan rumus K-R. 20 sebagai

berikut:

$$
r_{11}=\left(\frac{n}{n-1}\right)\left(\frac{S^{2}-\sum p q}{S^{2}}\right)
$$

Keterangan:

$\mathrm{r}_{11}=$ Reliabilitas tes secara keseluruhan

$\mathrm{p}=$ Proporsi subjek yang menjawab item dengan benar

$\mathrm{q}=$ Proporsi subjek yang menjawab item dengan salah $(\mathrm{q}=1-\mathrm{p})$

$\sum \mathrm{pq}=$ Jumlah hasil perkalian antara $\mathrm{p}$ dan $\mathrm{q}$

$\mathrm{n} \quad=$ Banyaknya item

$\mathrm{S} \quad=$ Standar deviasi dari tes

(Suharsimi Arikunto, 2012: 115)

Soal dikatakan reliabel atau memiliki

Reliabilitas tinggi apabila koefisien Reliabilitasnya lebih dari atau sama dengan 0,70 . Soal yang memiliki koefisien 
Reliabilitas kurang dari 0,70 dinyatakan tidak reliabel atau memiliki Reliabilitas rendah.

\section{c. Tingkat Kesukaran}

Perhitungan Tingkat Kesukaran merupakan perhitungan proporsi antara siswa yang dapat menjawab benar suatu butir soal dengan jumlah seluruh peserta tes. Bilangan yang menunjukkan sukar mudahnya suatu soal disebut indeks kesukaran. Rumus yang digunakan untuk menghitung indeks kesukaran butir soal untuk bentuk soal objektif sebagai berikut:

Keterangan:

$$
P=\frac{B}{J S}
$$

$\mathrm{P} \quad=$ Indeks kesukaran

$\mathrm{B}=$ Banyaknya siswa yang menjawab soal dengan benar

JS = Jumlah seluruh siswa peserta tes

(Suharsimi Arikunto, 2012: 223)

Tabel 1. Klasifikasi Tingkat Kesukaran

\begin{tabular}{|l|l|}
\hline $\begin{array}{c}\text { Indeks } \\
\text { Kesukaran }\end{array}$ & \multicolumn{1}{|c|}{$\begin{array}{c}\text { Kategori Tingkat } \\
\text { Kesukaran }\end{array}$} \\
\hline $0 \quad-0,30$ & Sukar \\
\hline $0,31-0,70$ & Sedang \\
\hline $0,71-1,00$ & Mudah \\
\hline \multicolumn{3}{|c|}{ (Nana Sudjana, 2014: 147) } \\
\hline
\end{tabular}

\section{d. Daya Pembeda}

Menurut Zainal Arifin (2013:273), perhitungan daya pembeda adalah pengukuran sejauh mana suatu butir soal dapat membedakan peserta didik yang sudah menguasai kompetensi dengan peserta didik yang belum menguasai kompetensi. Daya Pembeda dapat diketahui dengan melihat besar kecilnya indeks diskriminasi soal. Rumus yang digunakan untuk menentukan indeks diskriminasi soal objektif yaitu:

Keterangan:

$$
D=\frac{B_{A}}{J_{A}}-\frac{B_{B}}{J_{B}}=P_{A}-P_{B}
$$

$\mathrm{J}=$ Jumlah peserta tes

$\mathrm{J}_{\mathrm{A}}=$ Banyaknya peserta kelompok atas
$\mathrm{J}_{\mathrm{B}}=$ Banyaknya peserta kelompok bawah

$\mathrm{B}_{\mathrm{A}}=$ Banyaknya peserta kelompok atas yang menjawab soal dengan benar

$\mathrm{B}_{\mathrm{B}}=$ Banyaknya peserta kelompok bawah yang menjawab soal dengan benar

$\mathrm{P}_{\mathrm{A}}=$ Proporsi peserta kelompok atas yang menjawab benar

$\mathrm{P}_{\mathrm{B}}=$ Proporsi peserta kelompok bawah yang menjawab benar

(Suharsimi Arikunto, 2012: 228-229)

Penentuan Daya Pembeda dapat menggunakan klasifikasi sebagai berikut:

$\mathrm{D}=0,00-0,20=$ jelek (poor)

$\mathrm{D}=0,21-0,40=$ cukup (satisfactory)

$\mathrm{D}=0,41-0,70=$ baik (good)

$\mathrm{D}=0,71-1,00=$ baik sekali (excellent)

$\mathrm{D}=$ negatif, semuanya tidak baik. Jadi, sebaiknya dibuang.

(Suharsimi Arikunto, 2012: 232)

\section{e. Efektivitas Pengecoh}

Sebuah pengecoh dikatakan telah dapat menjalankan fungsinya dengan baik apabila pengecoh tersebut mempunyai daya tarik sedemikian rupa sehingga siswa yang kurang menguasai konsep merasa bimbang dan pada akhirnya mereka terkecoh untuk memilih pengecoh sebagai jawaban benar (Anas Sudijono, 2015: 410). Efektivitas Pengecoh dapat dilihat dengan menghitung indeks pengecoh. Rumus untuk menghitung indeks pengecoh yaitu sebagai berikut:

$$
\mathrm{IP}=\frac{\mathrm{P}}{(\mathrm{N}-\mathrm{B}) /(\mathrm{n}-1)} \times 100 \%
$$

Keterangan:

$\mathrm{IP}=$ Indeks pengecoh

$\mathrm{P}=$ Jumlah peserta didik yang memilih pengecoh

$\mathrm{N}=$ Jumlah peserta didik yang mengikuti tes

$\mathrm{B}=$ Jumlah peserta didik yang menjawab benar pada setiap soal

$\mathrm{n}$ = Jumlah alternatif jawaban (opsi)

$1=$ Bilangan tetap

Kriteria Efektivitas Pengecoh berdasarkan angka indeks pengecoh sebagai berikut: 
Tabel 2. Kriteria Efektivitas Pengecoh

\begin{tabular}{|l|l|}
\hline \multicolumn{1}{|c|}{ Indeks Pengecoh } & \multicolumn{1}{c|}{ Kualitas } \\
\hline $76 \%-125 \%$ & Sangat baik \\
\hline $\begin{array}{l}51 \%-75 \% \text { atau } \\
126 \%-150 \%\end{array}$ & Baik \\
\hline $\begin{array}{l}26 \%-50 \% \text { atau } \\
151 \%-175 \%\end{array}$ & Kurang baik \\
\hline $\begin{array}{l}0 \%-25 \% \text { atau } \\
176 \%-200 \%\end{array}$ & Jelek \\
\hline Lebih dari $200 \%$ & Sangat jelek \\
\hline \multicolumn{2}{|c|}{ (Zainal Arifin, 2013: 280) } \\
\hline
\end{tabular}

Untuk menentukan Efektivitas

Pengecoh setiap butir soal digunakan skala dengan rentang antara sangat baik sampai sangat tidak baik.

1) Efektivitas Pengecoh butir soal dikatakan sangat baik apabila keempat pengecoh berfungsi.

2) Efektivitas Pengecoh butir soal dikatakan baik apabila tiga pengecoh berfungsi.

3) Efektivitas Pengecoh butir soal dikatakan kurang baik apabila dua pengecoh berfungsi.

4) Efektivitas Pengecoh butir soal dikatakan tidak baik apabila hanya satu pengecoh berfungsi.

5) Efektivitas Pengecoh butir soal dikatakan sangat tidak baik apabila semua pengecoh tidak berfungsi.

Penentuan kualitas butir soal ditinjau dari Validitas butir, Tingkat Kesukaran, Daya Pembeda dan Efektivitas Pengecoh adalah sebagai berikut:

a. Butir soal dikatakan memiliki kualitas baik apabila:

1) Ditinjau dari Validitas, butir soal dikatakan valid apabila $r_{p b i}$ lebih besar atau sama dengan $r_{\text {tabel }}$ pada taraf signifikansi 5\% sesuai dengan jumlah peserta tes.

2) Ditinjau dari Tingkat Kesukaran, butir soal yang baik adalah butir soal yang termasuk memiliki Tingkat Kesukaran sedang dengan indeks kesukaran 0,31-0,70.
3) Ditinjau dari Daya Pembeda butir soal dikatakan baik apabila termasuk dalam kategori Daya Pembeda sedang dengan Indeks Daya Pembeda 0,21-0,40; kategori Daya Pembeda baik dengan indeks Daya Pembeda 0,41-0,70 dan kategori Daya Pembeda baik sekali dengan indeks Daya Pembeda 0,71-1,00.

4) Ditinjau dari Efektivitas Pegecoh, butir soal dikatakan baik apabila termasuk kategori baik atau memiliki 3 pengecoh yang berfungsi dan kategori sangat baik atau memiliki 4 pengecoh berfungsi.

b. Butir soal dikatakan memiliki kualitas yang kurang baik apabila hanya memenuhi tiga dari keempat kriteria butir soal yang baik.

c. Butir soal dikatakan memiliki kualitas yang tidak baik apabila hanya memenuhi dua atau kurang dari dua kriteris dari keempat kriteria butir soal yang baik.

\section{HASIL PENELITIAN DAN PEMBA- HASAN \\ Validitas}

Berdasarkan hasil analisis Validitas butir soal Pra Ujian Nasional Mata Pelajaran Ekonomi Akuntansi Kelas XII IIS SMA Negeri 1 Magelang Tahun Ajaran 2015/2016, diketahui terdapat 29 butir soal valid atau sebesar $72,5 \%$ dan butir soal tidak valid berjumlah 11 butir atau 27,5\%.

Analisis Validitas butir soal dapat ditelusuri dengan menggunakan rumus korelasi point biserial $\left(\mathrm{r}_{\mathrm{pbi}}\right)$. Indeks korelasi point biserial yang diperoleh dari hasil perhitungan dikonsultasikan dengan $r_{\text {tabel }}$ pada taraf signifikansi 5\% sesuai jumlah subjek atau jumlah peserta tes. Subjek dalam penelitian ini berjumlah 112 siswa, sehingga dengan $\mathrm{n}=112$ didapatkan hasil $\mathrm{r}_{\text {tabel }}$ sebesar 0,184. Jika koefisien korelasi point biserial lebih besar atau sama dengan $r_{\text {tabel}}$, maka butir soal tersebut dinyatakan valid, tetapi jika koefisien korelasi point biserial lebih 


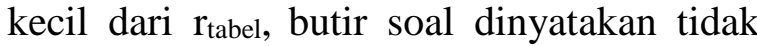
valid.

Sebagai tindak lanjut dari hasil analisis Validitas butir soal, butir soal yang valid dapat digunakan kembali pada tes berikutnya atau disimpan di bank soal. Butir soal yang tidak valid diperbaiki dengan disesuaikan pada indikator pencapaian maupun disesuaikan dengan teknik penyusunan butir soal.

\section{Reliabilitas}

Hasil perhitungan Reliabilitas soal Pra Ujian Nasional Mata Pelajaran Ekonomi Akuntansi Kelas XII IIS SMA Negeri 1 Magelang Tahun Ajaran 2015/2016 menunjukkan bahwa soal memiliki koefisien Reliabilitas $\left(\mathrm{r}_{11}\right)$ sebesar 0,62.

Reliabilitas soal dapat dihitung dengan menggunakan rumus KR-20, dengan interpretasi apabila koefisien Reliabilitas lebih dari atau sama dengan 0,70 maka soal tersebut dinyatakan reliabel atau memiliki Reliabilitas tinggi dan apabila koefisien Reliabilitas kurang dari 0,70 maka soal termasuk dalam kategori tidak reliabel atau memiliki Reliabilitas rendah. Hasil tersebut berarti bahwa soal Pra Ujian Nasional Mata Pelajaran Ekonomi Akuntansi Kelas XII IIS SMA Negeri 1 Magelang Tahun Ajaran 2015/2016 termasuk dalam kategori soal dengan Reliabilitas rendah atau tidak reliabel karena $\mathrm{r}_{11}$ kurang dari 0,70 .

\section{Tingkat Kesukaran}

Hasil Analisis Tingkat Kesukaran Soal Pra Ujian Nasional Mata Pelajaran Ekonomi Akuntansi Kelas XII IIS SMA Negeri 1 Magelang Tahun Ajaran 2015/2016 menunjukkan bahwa terdapat 6 butir soal atau $15 \%$ termasuk kategori sukar, 24 butir soal atau $60 \%$ termasuk kategori sedang dan 10 butir soal atau $25 \%$ termasuk kategori mudah.

Setelah diperoleh hasil analisis Tingkat Kesukaran, kemudian dilakukan tidak lanjut terhadap butir-butir soal tersebut. Anas Sudijono (2015: 376) menjelaskan tindak lanjut yang perlu dilakukan oleh tester yaitu sebagai berikut:

a. Untuk butir-butir soal yang berdasarkan hasil analisis termasuk dalam kategori baik (tingkat kesukarannya sedang), sebaiknya butir soal tersebut disimpan dalam bank soal, untuk selanjutnya dikeluarkan lagi pada tes-tes hasil belajar pada waktu yang akan datang.

b. Untuk butir-butir soal yang termasuk dalam kategori sukar, ada tiga kemungkinan tindak lanjut, yaitu:

1) Butir soal tersebut dibuang dan tidak akan dikeluarkan lagi dalam tes-tes hasil belajar yang akan datang.

2) Diteliti ulang, dilacak dan ditelusuri sehingga dapat diketahui faktor yang menyebabkan butir soal tersebut sulit dijawab oleh testee. Setelah dilakukan perbaikan kembali, butir-butir soal tersebut dikeluarkan lagi dalam tes hasil belajar yang akan datang.

3) Butir-butir soal yang terlalu sukar sewaktu-waktu dapat digunakan dalam tes-tes yang sifatnya sangat ketat, dalam artian sebagian besar testee tidak akan diluluskan dalam tes seleksi tersebut.

c. Untuk butir-butir soal yang termasuk dalam kategori mudah, juga terdapat tiga kemungkinan tindak lanjut, yaitu:

1) Butir soal dibuang dan tidak akan dikeluarkan lagi dalam tes-tes hasil belajar yang akan datang.

2) Diteliti ulang, dilacak dan ditelusuri secara cermat guna mengetahui faktor-faktor yang menyebabkan butir soal tersebut dapat dijawab benar oleh hampir seluruh testee. Setelah dilakukan perbaikan, soal yang bersangkutan dicoba untuk dikeluarkan lagi pada tes hasil belajar berikutnya, guna mengetahui apakah tingkat kesukaran soal menjadi lebih baik dari sebelumnya atau tidak. 
3) Butir-butir soal yang termasuk dalam kategori terlalu mudah dapat dimanfaatkan pada tes atau seleksi yang sifatnya longgar, dalam arti bahwa sebagian besar dari testee akan dinyatakan lulus dalam seleksi tersebut.

\section{Daya Pembeda}

Hasil analisis Daya Pembeda soal Pra Ujian Nasional Mata Pelajaran Ekonomi Akuntansi Kelas XII IIS SMA Negeri 1 Magelang Tahun Ajaran 2015/2016 menunjukkan bahwa butir soal dengan Daya Pembeda jelek berjumlah 13 butir atau 32,5\%; Daya Pembeda sedang berjumlah 17 butir atau 42,5\%; Daya Pembeda baik berjumlah 8 butir atau 20\%; Daya Pembeda baik sekali tidak ada atau 0\% dan Daya Pembeda negatif atau jelek sekali 2 butir atau $5 \%$.

Tindak lanjut dari hasil analisis Daya Pembeda butir soal yaitu butir soal yang memiliki Daya Pembeda sedang, baik dan baik sekali sebaiknya disimpan dalam bank soal untuk dikeluarkan lagi pada tes berikutnya, butir soal dengan Daya Pembeda jelek diperbaiki untuk dapat digunakan kembali pada tes berikutnya, dan butir soal dengan Daya Pembeda negatif atau jelek sekali lebih baik dibuang atau tidak digunakan kembali.

\section{Efektivitas Pengecoh}

Hasil analisis Efektivitas Pengecoh soal Pra Ujian Nasional Mata Pelajaran Ekonomi Akuntansi Kelas XII IIS SMA Negeri 1 Magelang Tahun Ajaran 2015/2016 menunjukkan bahwa 5 butir soal atau 12,5\% memiliki Efektivitas Pengecoh sangat baik, 5 butir soal atau 12,5\% memiliki Efektivitas Pengecoh baik, 16 butir soal atau 40\% memiliki Efektivitas Pengecoh kurang baik, 8 butir soal atau 20\% memiliki Efektivitas Pengecoh tidak baik dan 6 butir soal atau 15\% memiliki Efektivitas Pengecoh sangat tidak baik.
Butir soal yang memiliki Efektivitas Pengecoh sangat baik dan baik dapat disimpan dalam bank soal atau digunakan kembali pada tes berikutnya. Butir soal dengan Efektivitas Pengecoh kurang baik harus diperbaiki agar dapat menjadi baik sehingga dapat digunakan kembali pada tes berikutnya. Butir soal yang tidak baik atau sangat tidak baik tidak perlu digunakan kembali. Butir soal yang Efektivitas Pengecohnya tidak baik dan sangat tidak baik mengindikasikan bahwa pengecoh belum dapat berfungsi dengan baik, pengecoh tersebut tidak memiliki daya tarik bagi siswa yang kurang menguasai konsep atau materi.

\section{Hasil Analisis Validitas butir, Tingkat Kesukaran, Daya Pembeda dan Efektivitas Pengecoh}

Butir soal dapat disimpan di dalam bank soal atau digunakan kembali apabila memenuhi empat kriteria yaitu ditinjau dari Validitas butir soal termasuk butir soal valid, ditinjau dari Tingkat Kesukaran termasuk dalam kategori Tingkat Kesukaran sedang, ditinjau dari Daya Pembeda termasuk kategori Daya Pembeda sedang, baik dan baik sekali dan ditinjau dari Efektivitas Pengecoh termasuk butir soal dengan pengecoh baik dan sangat baik. Butir soal Pra Ujian Nasional Mata Pelajaran Ekonomi Akuntansi Kelas XII IIS SMA Negeri 1 Magelang Tahun Ajaran 2015/2016 yang dapat disimpan atau digunakan kembali berjumlah 5 butir atau $12,5 \%$ dengan Reliabilitas sebesar 0,39. Butir soal tersebut perlu dijaga kerahasiaannya untuk dapat dikeluarkan kembali pada ujian berikutnya.

Butir soal yang hanya memenuhi tiga dari keempat kriteria, sebaiknya diperbaiki. Butir soal Pra Ujian Nasional Mata Pelajaran Ekonomi Akuntansi Kelas XII IIS SMA Negeri 1 Magelang Tahun Ajaran 2015/2016 yang memenuhi tiga kriteria berjumlah 14 butir atau $35 \%$. Butir soal yang sudah diperbaiki dapat diujikan kembali untuk 
mengetahui apakah butir soal tersebut sudah menjalankan fungsinya atau belum.

Butir soal yang hanya memenuhi dua kriteria sebaiknya tidak digunakan kembali. Butir soal Pra Ujian Nasional Mata Pelajaran Ekonomi Akuntansi Kelas XII IIS SMA Negeri 1 Magelang Tahun Ajaran 2015/2016 yang hanya memenuhi dua kriteria berjumlah 21 butir atau 52,5\%. Butir soal tersebut sebaiknya tidak digunakan kembali, karena apabila hendak digunakan kembali memerlukan perbaikan yang signifikan.

\section{SIMPULAN DAN SARAN Simpulan}

Berdasarkan hasil analisis kualitas soal yang meliputi Validitas, Reliabilitas, Tingkat Kesukaran, Daya Pembeda dan Efektivitas Pengecoh, dapat disimpulkan bahwa butir soal yang dapat digunakan kembali maupun disimpan di dalam bank soal berjumlah 5 butir atau $12,5 \%$ yaitu butir soal nomor $8,23,28,33$ dan 34 dengan Reliabilitas 0,39. Butir soal yang perlu diperbaiki berjumlah 14 butir atau $35 \%$ dan butir soal yang sebaiknya tidak digunakan kembali berjumlah 21 butir atau 52,5\%. Hal tersebut diperoleh dari hasil analisis sebagai berikut:

a. Ditinjau dari Validitas butir soal, jumlah butir soal Pra Ujian Nasional Mata Pelajaran Ekonomi Akuntansi Kelas XII IIS SMA Negeri 1 Magelang Tahun Ajaran 2015/2016 yang valid sebesar $72,5 \%$ atau 29 butir dan jumlah butir soal yang tidak valid sebesar $27,5 \%$ atau 11 butir.

b. Ditinjau dari Reliabilitas, soal Pra Ujian Nasional Mata Pelajaran Ekonomi Akuntansi Kelas XII IIS SMA Negeri 1 Magelang Tahun Ajaran 2015/2016 merupakan soal yang tidak reliabel atau memiliki Reliabilitas rendah karena koefisien Reliabilitasnya kurang dari 0,70 yaitu hanya sebesar 0,62 .

c. Ditinjau dari Tingkat Kesukaran, soal Pra Ujian Nasional Mata Pelajaran Ekonomi Akuntansi Kelas XII IIS SMA
Negeri 1 memiliki Tingkat Kesukaran yang baik atau dapat dikatakan proporsional, dilihat dari jumlah butir soal yang termasuk dalam kategori sukar berjumlah 6 butir atau 15\%, butir soal yang termasuk dalam kategori sedang berjumlah 24 butir atau $60 \%$ dan butir soal dengan kategori mudah berjumlah 10 butir atau $25 \%$.

d. Ditinjau dari Daya Pembeda butir soal Pra Ujian Nasional Mata Pelajaran Ekonomi Akuntansi Kelas XII IIS SMA Negeri 1 Magelang Tahun Ajaran 2015/2016, jumlah butir soal yang memiliki Daya Pembeda jelek 13 butir atau $32,5 \%$, butir soal yang memiliki Daya Pembeda sedang berjumlah 17 butir atau 42,5\%, butir soal yang memiliki Daya Pembeda baik berjumlah 8 butir atau $20 \%$, butir soal dengan Daya Pembeda negatif berjumlah 2 butir atau $5 \%$.

e. Ditinjau dari Efektivitas Pengecoh, dapat disimpulkan soal Pra Ujian Nasional Mata Pelajaran Ekonomi Akuntansi Kelas XII IIS SMA Negeri 1 Magelang Tahun Ajaran 2015/2016 belum memiliki Efektivitas Pengecoh yang baik, dilihat dari jumlah butir soal dengan Efektivitas Pengecoh sangat baik berjumlah 5 butir atau 12,5\%; butir soal dengan Efektivitas Pengecoh baik berjumlah 5 butir $12,5 \%$; butir soal dengan Efektivitas Pengecoh kurang baik berjumlah 16 butir atau $40 \%$; butir soal dengan Efektivitas Pengecoh tidak baik berjumlah 8 butir atau 20\% dan butir soal dengan Efektivitas Pengecoh sangat tidak baik berjumlah 6 butir atau $15 \%$.

\section{Saran}

Berdasarkan hasil analisis Validitas, Reliabilitas, Tingkat Kesukaran, Daya Pembeda dan Efektivitas Pengecoh terhadap soal Pra Ujian Nasional Mata Pelajaran Ekonomi Akuntansi Kelas XII IIS SMA Negeri 1 Magelang Tahun Ajaran 
2015/2016, maka saran yang dapat saya ajukan sebagai berikut:

a. Butir soal nomor $8,23,28,33$ dan 34 sebaiknya disimpan di dalam bank soal dan dijaga kerahasiaannya agar dapat dikeluarkan kembali pada tes berikutnya.

b. Butir soal nomor 2, 4, 14, 17, 19, 22, 25, 29, 31, 32, 37, 38, 39, 40 perlu diperbaiki kemudian diujikan kembali untuk dapat mengetahui apakah soal sudah berfungsi atau belum.

c. Butir soal nomor $1,3,5,6,7,9,10,11$, $12,13,15,16,18,20,21,24,26,27,30$, $35, \quad 36$ sebaiknya tidak digunakan kembali pada tes berikutnya karena memerlukan perbaikan yang signifikan.

d. Guru sebagai pembuat soal perlu memperhatikan langkah pengembangan tes, sehingga guru memiliki lebih banyak butir soal yang berkualitas.

\section{DAFTAR PUSTAKA}

Afni Mayla Syaroh. (2015). Analisis Butir Soal Ujian Akhir Semester Gasal Mata Pelajaran Akuntansi Keuangan Kelas XI Akuntansi SMK Negeri 7 Yogyakarta Tahun Ajaran 2014/2015. Skripsi. Yogyakarta: FE UNY.

Anas Sudijono. (2015). Pengantar Evaluasi Pendidikan. Jakarta: PT Raja Grafindo Persada.

Djemari Mardapi. (2008). Teknik Penyusunan Instrumen Tes dan Nontes. Yogyakarta: Mitra Cendikia.

Eko Putro Widoyoko. (2014). Penilaian Hasil Pembelajaran di Sekolah. Yogyakarta: Pustaka Pelajar.

Kusaeri dan Suprananto. (2012). Pengukuran dan Penilaian Pendidikan. Yogyakarta: Graha Ilmu.

Nana Sudjana. (2014). Penilaian Hasil Proses Belajar Mengajar. Bandung: PT Remaja Rosdakarya.
Nana Syaodih. (2012). Metode Penelitian Pendidikan. Bandung: PT Remaja Rosdakarya.

Raras Duhita. (2015). Analisis Butir Soal Ujian Akhir Semester Gasal Mata Pelajaran Pengantar Akuntansi Kelas X Akuntansi SMK Negeri 1 Godean Tahun Ajaran 2014/2015. Skripsi. Yogyakarta: FE UNY.

Suharsimi Arikunto. (2012). Dasar-Dasar Evaluasi Pendidikan: Edisi 2. Jakarta: Bumi Aksara.

Sukardi. (2012). Evaluasi Pendidikan: Prinsip \& Operasionalnya. Jakarta: Bumi Aksara. (2013). Metodologi Penelitian Pendidikan. Jakarta: Bumi Aksara.

Sukiman. (2012). Pengembangan Sistem Evaluasi. Yogyakarta: Insan Madani.

Sumarna Surapranata. (2009). Analisis, Validitas, Reliabilitas dan Interpretasi Hasil Tes Implementasi Kurikulum 2004. Bandung: PT Remaja Rosdakarya.

Tony Wijaya. (2011). Manajemen Kualitas Jasa. Jakarta: PT Indeks.

Wika Sevi Oktanin. (2015). Analisis Butir Soal Ujian Akhir Semester Genap Mata Pelajaran Ekonomi Akuntansi Kelas XI IPS SMA N 1 Kalasan Tahun Ajaran 2013/2014. Skripsi. Yogyakarta: FE UNY.

Zainal Arifin. (2012). Penelitian Pendidikan: Metode dan Paradigma Baru. Bandung: PT Remaja Rosdakarya. (2013). Evaluasi Pembelajaran.

Bandung: PT Remaja Rosdakarya. 